\title{
Bombay Phenotype: Report of 2 Cases
}

\author{
TFA DIPTA ${ }^{\mathrm{a}}$, KN HOSSAIN ${ }^{\mathrm{b}}$, A KHATUN $^{\mathrm{c}}, \mathrm{M}^{\mathrm{RAHMAN}}{ }^{\mathrm{d}}$, AZ HOSSAIN $^{\mathrm{e}}$, A WAHED $^{\mathrm{f}}, \mathrm{N} \mathrm{SHIL}^{\mathrm{g}}$
}

\begin{abstract}
Summary:
Two cases of the rare blood group "Bombay phenotype" are discussed here. This rare blood group, Bombay (Oh) was first established by Bhende et al in Bombay (Mumbai), in 1952.In the $A B O$ ( $A B H)$ blood group system, the ' $O$ 'antigen represents the lack of $A$ or $B$ antigens; however it has the most amount of $H$ antigen. If the $\mathrm{H}$ gene is absent, which is extremely rare, $H$ substance can not be formed and subsequent $A$ and $B$ antigens can not also be formed. Absence of $H$ gene results in the Bombay phenotype (Oh) ${ }^{1-6,7-13}$. Individuals with the Bombay phenotype develop anti-H antibodies. This is the reason that undetected Bombay individuals (typically typed as $O$ individuals) will be cross match incompatible with $O$
\end{abstract}

\section{Introduction:}

The existence of a human $\mathrm{H} / \mathrm{h}$ genetic polymorphism was first established by Bhende et al in Bombay (Mumbai), in 1952. In ABO (ABH) blood group system, the ' $\mathrm{O}$ ' antigen represents the lack of $\mathrm{A}$ or $\mathrm{B}$ antigens; but individuals with $\mathrm{O}$ blood group has the most amount of the $\mathrm{H}$ antigen as none have been converted to $\mathrm{A}$ or $\mathrm{B}$

a. Tashmim Farhana Dipta, Associate Professor and Head, Department of Transfusion Medicine, BIRDEM and Ibrahim Medical College, E-mail: tashmim@yahoo.com, Mobile: 01817049343.

b. Kazi Nawshad Hossain, Head, Blood Bank and Transfusion Services, ICDDR, B.

c. Ayesha Khatun, Associate Professor, Transfusion Medicine Department, BSMMU.

d. Manjuma Rahman, Medical officer, Transfusion Medicine Department, Square Hospitals Ltd.

e. Ahmed Zahid Hossain, Associate Consultant, Department of Paediatric Surgery, Square Hospitals Ltd.

f. Amer Wahed, Associate Director, Medical Services, Square Hospitals Ltd.

g. Nittyananda Shil, Associate Professor, Transfusion Medicine Department, BSMMU.

Address of Correspondence: Dr. Tashmim Farhana Dipta, F.C.P.S. (Haematology), MTM (Transfusion Medicine), MBBS, Specialty: Haematology and blood transfusion, Associate Professor and Head, Dept. of Transfusion Medicine,BIRDEM and Ibrahim Medical College, E-mail : tashmim@yahoo.com, Mobile: 01817049343

Received: 1 November 2010

Accepted: 20 September 2011 individuals. Bombay phenotype individuals can only receive blood from other Bombay individuals. In India, 1 in 10,000 has been found to have "Bombay" blood group. Where as, in Bangladesh till now only nine persons with Bombay $(\mathrm{Oh})$ blood group have been formally reported by the Transfusion Medicine Department of Bangabandhu Sheikh Mujib Medical University (BSMMU). Using two cases we would like to discuss strategies to properly diagnose cases of Bombay phenotype in Bangladesh.

Key Words: Bombay blood group, Bombay phenotype, ' $\mathrm{O}$ ' blood group.

(J Bangladesh Coll Phys Surg 2011; 29: 241-243)

antigens. If the $H$ gene is absent, which is extremely rare, $\mathrm{H}$ substance can not be formed and subsequent $\mathrm{A}$ and $\mathrm{B}$ antigens can not also be formed. Absence of $\mathrm{H}$ gene results in the Bombay phenotype (Oh) ${ }^{1-6,7-13}$. Individuals with the Bombay phenotype develop anti$\mathrm{H}$ antibodies. This is the reason that undetected Bombay individuals (typically typed as $\mathrm{O}$ individuals) will be cross match incompatible with $\mathrm{O}$ individuals. Bombay phenotype individuals can only receive blood from other Bombay individuals. In India, 1 in 10,000 has been found to have "Bombay" blood group. Where as, in Bangladesh till now only nine persons with Bombay (Oh) blood group have been formally reported by the Transfusion Medicine Department of Bangabandhu Sheikh Mujib Medical University (BSMMU).

\section{Case Reports:}

\section{Case -1:}

A 52 year old O Rh positive Muslim male 'M' who was anaemic and scheduled for bypass cardiac surgery at BSMMU required $\mathrm{O} R \mathrm{R}$ positive packed red cells. Cross match with $\mathrm{O} R \mathrm{Rh}$ positive units resulted in incompatibility. The blood group of both patient and donor was re checked using both cell typing and serum typing procedure, with same results. However, with anti$\mathrm{H}$ lectin the patient showed negative reaction, whereas, strong positive reaction showed by donor who is confirmed as $\mathrm{O}$ Rh D positive. Thus the patient lacks 
any $\mathrm{H}$ antigen. It was concluded that he was a patient with Bombay phenotype.

Case-2:

A 35 year old $\mathrm{O}$ Rh positive Hindu female was admitted to Square Hospitals Ltd. She was a known case of pancreatic carcinoma on chemotherapy. She required blood transfusion for correction of anaemia and was cross match incompatible with multiple $\mathrm{O} R$ ph positive units. Subsequent testing with anti-H lection confirmed her to be a case of Bombay phenotype.

\section{Materials and method:}

For confirmation and final diagnosis each case was sent to the Department of Transfusion Medicine, BSMMU. Forward grouping was done with Anti-A, Anti-B, Anti$\mathrm{AB}$ (Monoclonal antibody, Biotec Laboratories, UK) and Anti-D (Monoclonal antibody IgG and IgM, Biotec Laboratories, UK) and reverse grouping was done with freshly prepared A-cell, B-cell, O-cell (Washed for four times , 5\% saline suspension). Strong agglutination reaction $(4+)$ was observed with panel "O" cell in reverse grouping. There was also reaction with both $\mathrm{A}$ and B cell in reverse grouping. However, auto/ self control (washed patient's cells with patient's serum) showed negative result. Anti-A, Anti-B and Anti-AB sera also showed negative agglutination with patient cells. With anti -H lectin (Tulip Diagnostic, India) patient's cell showed no evidence of agglutination macroscopically and microscopically. As parents of these patients were not alive, family study includes only brother, sister and children. None showed Bombay blood group and these individuals were not chimeric either. The patient's saliva did not show presence of A, $\mathrm{B}$ and $\mathrm{H}$ antigens. They did show presence of Le a substance. Thus they were non secretors; Le $(\mathrm{a}+\mathrm{b}-)$.

\section{Discussion:}

The expression of A and B antigens are determined by the $H$ and $S e$ genes, which both give rise to glycosyl transferase that add L- fucose, producing the $\mathrm{H}$ antigen ${ }^{1-}$ ${ }^{5}$.The presence of an $A$ or $B$ gene results in the production of further glycosyltransferase which convert $\mathrm{H}$ substance into $\mathrm{A}$ and $\mathrm{B}$ antigens, respectively. $A$ gene causes Nacetyle-galactosamine to be added to $\mathrm{H}$ substance, producing $A$ antigen and $B$ gene causes D-galactose to be added to $\mathrm{H}$ substance, producing $\mathrm{B}$ antigen ${ }^{5,6}$. If both $A$ and $B$ genes are present, some $\mathrm{H}$-chains are converted to 'A' antigen and are some converted to ' $\mathrm{B}$ ' antigen, produces ' $\mathrm{AB}$ ' ${ }^{2,5}$. Since the $O$ gene produces an inactive transferase, $\mathrm{H}$ substance persists unchanged as group $\mathrm{O}$. Thus the ' $\mathrm{O}$ ' antigen represents the lack of A or B antigens; but it has the most amount of the $\mathrm{H}$ antigen. If $H$ gene is absent, which is extremely rare, no $\mathrm{H}$ substance can be formed and therefore no $\mathrm{A}$ or $\mathrm{B}$ antigen can be formed as well. This results in what is referred to as the Bombay phenotype (Oh) ${ }^{1-6,7-13}$. In Bombay blood group individuals there is anti-A, anti$\mathrm{B}$, anti-AB and anti-H which are all active at $37^{0} \mathrm{C}^{2-5}$ ,11- 16 .The use of Anti-H lectin and detection of secretor status by using saliva are also important for diagnosis, as the Bombay group people are non secretors ${ }^{4,5}$. In Bangladesh at present $\mathrm{ABO}$ and $\mathrm{Rh}$ typing is done by forward grouping in the vast majority of cases. Rarely reverse grouping is utilized. This is resulting in lack of diagnosis of Bombay phenotypes as well as incorrect blood group typing. Hemolytic transfusion reactions are a serious threat in all such cases. So reverse grouping as well as incorporation of $\mathrm{O}$ cells in reverse grouping is very important.

\section{Conclusion:}

Reverse grouping (serum typing) with O cell control, anti-H lectin and detection of secretor status are all important tools for detecting the Bombay group individuals in our country. At the very minimum incorporation of ' $\mathrm{O}$ ' cell in reverse typing is very important in detecting this rare, but clinically important blood group.

\section{Acknowledgement:}

We are very grateful to the patients and their family members for their sincere cooperation during various test procedures. We would also like to express our gratitude to all doctors and technical staff of the Transfusion Medicine Department of BSMMU, Square Hospitals Ltd, United Hospital and BIRDEM for their co-operation.

\section{References:}

1. Bhende YM, Deshpande CK, Bhatia HM, Sanger R, Race RR, Morgan WTJ and Watkins WMA. "New" blood group character related to the ABO system. Lancet 1952, 1: 903-4.

2. Brozovic B, Brozovic M. Manual of Clinical Blood Transfusion, $1^{\text {st }}$ ed. Charchill Livingstone, USA, 1986; 1-19.

3. Balgir R.S. Detection of a rare blood group "Bombay (Oh) phenotype" among the Kutia Khondh Primitive Tribe of Orissa, India. Int J Hum Genet; 2005; 5 (3): 193-8. 
4. Rahman M, Abdullah AZ, Hussain M, Haque KM, Hossain MM, Bangladesh Med Research Council Bulletin.1990. Dec: 16 (20): 75-85.

5. Tashmim Farhana Dipta, Asadul Islam .A rare blood group found in Bangladeshi population. Bangladesh J Pathol 2010(1) 25-7.

6. Lewis S. M, Bain B. J, Bates I. Dacie and Lewis Practical Haematology, 10th edition, Churchill Livingstone, 2006; 481522 .

7. Konami Y, Tsuji T, Toyoshima S, Matsumoto I, Osawa T. Sugar binding specificities of anti-H (O) lectins disclosed by use of fucose-containing human milk oligosaccharides as binding inhibitors. Chem Pharm Bull (Tokyo). 1989 Mar; 37(3):729-31.

8. Daniels GL. Studies on anti-H reagents. Rev Fr Transfrus Immunohematol; 1984 Oct; 27 (5): 603-12.

9. Hoffbrand. AV, Catovsky D, Tuddenham E. G. D. Post graduate Haematolgy, 5th ed. , Blackwell Publishing, 2005; 225-48.

10. Blumenfeld OO, Patnaik SK. Allelic genes of blood group antigens: a source of human mutations and cSNPs documented in the Blood Group Antigen Gene Mutation Database. Human Mutation. 2004 Jan; 23(1):8-16.

11. Murphy M.F, Pamphilon D. H. Practical Transfusion Medicine, $2^{\text {nd }}$ edition, Blackwell Publishing, 2005; 24-33.

12. Makroo R N. Compendium of Transfusion Medicine, $1^{\text {st }}$ edition, J. Mitra \& Co. Ltd. 1999; 20-44.

13. Mollison PL, Engelfriet C P, Contreras M. Blood Transfusion in Clinical Medicine $9^{\text {th }}$ edition , Blackwell Scientific Publications , 1994; 148-203.

14. Dodd BE, Lincoln PJ. Serological studies of the H activity of Oh red cells with various anti-H reagents, Vox Sang; 1978 Sep; 35(3):168-75.

15. Wikipedia, free encyclopedia, hh antigen system,

http://en.wikipedia.org/wiki/Hh_antigen_system, searched on $4^{\text {th }}$ June 2010.

16. J Kelly, L K Ernst, R D Larsen, J G Bryant, J S Robinson, and $\mathrm{J}$ B Lowe. Molecular basis for $\mathrm{H}$ blood group deficiency in Bombay (Oh) and para-Bombay individuals. Proc Natl Acad Sci USA. 1994 June 21; 91(13): 5843-47. 